\title{
The Airspace Tribunal and the case for a new human right to protect the freedom to live without physical or psychological threat from above
}

\author{
Nick Grief*
}

A little over one hundred years ago, on 13 October 1919, the Convention Relating to the Regulation of Aerial Navigation was concluded in Paris. ${ }^{1}$ For the first time, an international treaty proclaimed the principle that every State has complete and exclusive sovereignty in the airspace above its land and sea territory. ${ }^{2}$ That principle was subsequently confirmed and restated by the Chicago Convention on International Civil Aviation 1944. ${ }^{3}$ Since then, questions such as where the boundary between airspace and outer space lies ${ }^{4}$ and how far up a property owner's rights extend ${ }^{5}$ have been keenly debated. However, it is not appropriate to think about airspace just in terms of sovereignty or property rights. We also need to be concerned about the wider human rights dimension, bearing in mind that every State must respect the human rights of every individual within its jurisdiction. ${ }^{6}$ After the end of World War 2, the adoption of the Universal Declaration of Human Rights (UDHR) ${ }^{7}$ and of regional instruments such as the European Convention on Human Rights $(E C H R)^{8}$ marked the inception of modern international human rights law $^{9}$ which restricts the exercise of State sovereignty. Arguably, however, the human rights proclaimed in these and other instruments, including the right to life, liberty and the security of

\footnotetext{
* Professor of Law, Kent Law School and an Associate Tenant at Doughty Street Chambers.

${ }^{1}$ LNTS, vol 11, p 173.

2 Paris Convention, Art 1: 'The Contracting States recognise that every State has complete and exclusive sovereignty in the airspace above its territory and territorial waters.'

${ }^{3}$ UNTS, vol 15, p 295. Art 1 of the Chicago Convention declares: 'The contracting States recognise that every State has complete and exclusive sovereignty over the airspace above its territory.' Art 2 provides: 'For the purposes of this Convention the territory of a State shall be deemed to be the land areas and territorial waters adjacent thereto under the sovereignty... of such State.' In the Nicaragua case, ICJ Reports 1986, p 14, at para 212 , the International Court of Justice recognised that those provisions represent 'firmly established and longstanding tenets of customary international law'.

${ }^{4}$ Although there is no sovereignty in outer space and various approaches to delimitation have been proposed, the boundary between airspace and outer space has not yet been agreed. For practical purposes the upper limit of airspace is at least as high as an aircraft can fly.

${ }^{5}$ In Bernstein v Skyviews Ltd [1978] QB 479 at 488A, Griffiths J held that modern aviation necessitated 'restricting the rights of an owner in the airspace above his land to such height as is necessary for the ordinary use and enjoyment of his land and the structures upon it, and declaring that above that height he has no greater rights in the airspace than any other member of the public.'

${ }^{6}$ See e.g. ECHR, Art 1: 'The High Contracting Parties shall secure to everyone within their jurisdiction the rights and freedoms defined in... this Convention.'

${ }^{7}$ UN General Assembly Resolution 217A (III), 10 December 1948.

8 ETS No 5.

${ }^{9}$ Vaughan Lowe, International Law (Oxford: OUP, 2007), pp 11-12.
} 
person, ${ }^{10}$ are no longer sufficient to protect people against threats experienced from or through airspace. Further action is needed to ensure effective agency and voice. Developments in technology such as artificial intelligence and machine learning to process big data collected via aerial surveillance, and increasing existential threats from nuclear weapons and environmental pollution, demand a radical and robust rights-based response befitting 'the inherent dignity... of all members of the human family', not forgetting the generations unborn. ${ }^{11}$

The purpose of the Airspace Tribunal, a people's tribunal, is to consider the case for and against the recognition of a new human right to protect the freedom to live without physical or psychological threat from above. ${ }^{12}$ The inaugural hearing was held at Doughty Street Chambers, London in September 2018. There were eight speakers covering a wide range of expertise and lived experience..$^{13}$ Kirsty Brimelow $Q C^{14}$ was Counsel to the Tribunal. Her role was to ask each speaker two or three probing questions leading into wider discussion involving our audience of invited experts and members of the public, who are the Airspace Tribunal's 'judges'. ${ }^{15}$ The second hearing was in Sydney in October 2019. ${ }^{16}$ Further hearings will take place around the world ${ }^{17}$ so that we engage with different perspectives and voices. The hearings are being recorded and transcribed and the proceedings will form part of the drafting history of the proposed new human right. ${ }^{18}$

\footnotetext{
10 UDHR, Art 3.

${ }^{11}$ In its advisory opinion on the Legality of the Threat or Use of Nuclear Weapons, ICJ Reports 1996, p 226, at para 29, the International Court of Justice recognised that 'the environment is not an abstraction but represents the living space, the quality of life and the very health of human beings, including generations unborn.'

${ }^{12}$ The Airspace Tribunal was conceived by Nick Grief and Shona Illingworth and the rationale for this proposed new human right was outlined in an opinion piece published in the European Human Rights Law Review in June 2018. See Nick Grief, Shona Illingworth, Andrew Hoskins and Martin A Conway, 'The Airspace Tribunal: towards a new human right to protect the freedom to exist without a physical or psychological threat from above' [2018] EHRLR, Issue 3, pp 201-207.

13 http://airspacetribunal.org/about/london-hearing/.

${ }^{14}$ Doughty Street Chambers and at that time Chair of the Bar Human Rights Committee.

${ }^{15}$ Thus challenging the traditional state-centric view of how international law is created.

${ }^{16}$ https://www.thebiganxiety.org/events/shona-illngworth/.

17 Including Copenhagen, Hiroshima, South Africa and Toronto.

18 The preparatory work of a treaty is an important supplementary means of interpretation. See Anthony Aust, Modern Treaty Law and Practice (Cambridge: CUP, 2000), p 197 and Art 32 of the Vienna Convention on the Law of Treaties 1969.
} 
At the London hearing, Conor Gearty ${ }^{19}$ explained that human rights law is a creature of the success of civil society but warned against underestimating the opposition to deploying the language of rights in such a creative way:

'Where did the rights of persons with disabilities come from, if not starting life in a space like this? Where did the right to respect for indigenous people come from, if not from a space like this? And both have moved through events like this, social progress, affiliation by civil society activists, into the softest of soft law, [before] maturing into and taking shape as international, regional and domestic law... So the beauty of the subject is its flexibility. But it is also about struggle. We are battling against an entrenched version of what rights entail. There are good people who care about the death penalty and internment, and these are important issues. But their imagination does not go beyond that. People can be wellmeaning yet not have the imagination to see that the language can accommodate change.'

With that cautionary advice in mind, a particularly compelling argument in favour of recognising the proposed new human right is the psychological impact on civilians of threats experienced through airspace.

\section{The psychological impact of airborne threats}

Although more research on the psychological effects of weaponised drones is needed, there is evidence that drones cause civilians living in war zones to suffer 'anticipatory anxiety':

'One of the most salient psychological effects civilians describe is the pervasive sense of anticipatory apprehension of impending drone strikes (Amnesty International 2013). Drones may hover over targeted areas for hours as part of constant surveillance missions. Civilians describe feeling severely stressed, depressed, anxious, and being constantly reminded of deaths in prior strikes (Amnesty International 2013; Center for Civilians 2012). ${ }^{20}$

\footnotetext{
19 Professor of Human Rights Law, London School of Economics.

${ }^{20}$ Christopher J Ferguson et al, 'Psychological Dimensions of Drone Warfare', Curr Psychol, September 2017: http://christopheriferguson.com/Drones.pdf, $\mathrm{p}$ xx.
} 
Catherine Loveday ${ }^{21}$ touched on this in her evidence at the London hearing. She began by explaining that when something really traumatic happens to us, it makes a very rapid imprint on the brain and creates a very powerful, long-lasting memory that is easily cued. For some memories, sound is an especially powerful cue. Turning from actual experience to imagined experience, Professor Loveday said that one of the things our memory system allows us to do is to project ahead - to anticipate what is going to come. The fact that we anticipate the future and inhabit that future space is very important for someone living with threat:

'If you're living with threat, it's not that you are simply thinking about something that might happen to you. The way that our memory system works means that we're almost experiencing that. So the ability to imagine forward and think forward uses the same systems in the brain as thinking backwards. We can very powerfully recall to mind something that's happened to us in the past, and we can do the same thing with the future. So traumatic memories are very powerful, but traumatic imaginings are also very powerful. People who are anticipating a fearful event or trauma of some kind, or violence of any kind, or any kind of threat, are not just idly picturing it; they are to some extent living that experience.'

Concluding her evidence, Professor Loveday explained that when a threat is unseen, its psychological effect is worse because the lack of control and the lack of predictability are higher: 'So an unseen threat is always going to have a more powerful effect.' She added that physically and physiologically, children are particularly vulnerable to this effect.

These points were graphically underlined at the Sydney hearing. Sara Mir, who had lived through the Iran-Iraq war as a child, and Majid Rabet, who experienced the same war as an adult, recalled what it had been like to live under the constant threat of aerial bombardment and how psychological trauma continues today as a result of the ongoing threat of war. They described how attack from above had caused greater anxiety because it was unexpected.

Sara: 'When I think about the war, the most horrifying part was the bombardment. The safest place in war is [supposedly] when you're sitting at home, when you're not up front in the war. The trauma [at home] is

\footnotetext{
${ }^{21}$ Professor of Psychology, University of Westminster: a cognitive neuropsychologist and an expert on human memory.
} 
much worse than if you're fighting and ready for trauma to happen. It has longer effects because you're just not ready for it.'

Majid: 'From a child's perspective, we can't wipe the memory clean. As long as that memory exists, they've got that trauma. That's the reality. For that reason, space [above us] is meant to be secure.'

Sara also described how contemporary threats against Iran trigger traumatic memories not only for those living in Iran but also for a diaspora who no longer live there.

\section{A qualified right}

The proposed human right to live without physical or psychological threat from above would be a qualified right, not an absolute one; so interference with its enjoyment would be allowed as long as the interference was prescribed by law and 'necessary in a democratic society' (i.e. proportionate) to achieve a legitimate aim such as public safety or the prevention of harm. At the London hearing, Zrinka Bralo's ${ }^{22}$ recollection of her experiences during the Yugoslav wars underlined the importance of the right and its qualification. On the one hand, there had been

the most terrifying experience of these jets flying above the city of Sarajevo [to enforce the UN no-fly zone] that was supposed to make us feel safe, but somehow it didn't... because it was a reminder of all the other dangers that were flying in.'

And on the other, there were the advantages of the satellite imagery which had located mass graves following the Srebrenica genocide:

'I experienced the siege of Sarajevo for the first 18 months, when I was working as a young journalist, working with international war correspondents. And the reason why my mind was racing is because this whole debate around satellites and imagery that we receive from satellites is really important for the war in Bosnia... It was a commercial satellite that captured the pictures of mass graves, after the genocide was committed in Srebrenica.'

\footnotetext{
${ }^{22}$ CEO of Migrants Organise, a national organisation providing a platform where refugees and migrants organise for power, dignity and justice.
} 
Dr Melanie Klinkner ${ }^{23}$ made a similar point in her evidence:

'In 1995 The Guardian ran a headline "Spy pictures 'show Bosnia massacre'". ${ }^{24}$ Subsequently that information triggered investigations that led ultimately to the conviction of Radovan Karadžić and Ratko Mladić. And in Cambodia, Burundi, North Korea, similar pictures have emerged...' For his part, Professor Kevin Bales $\mathrm{CMG}^{25}$ explained how satellites are being used to detect slavery and other human rights abuses as well as environmental destruction.

\section{Do we need the proposed human right?}

There are two related aspects to this question: first, are not existing human rights adequate to ensure the protection we are seeking; and secondly, is the proposed right framed correctly?

As we argued in our EHRLR article, although it might be contended that what we are advocating - a right protecting the freedom to live without physical or psychological threat from above - is already covered by existing rights such as the right to respect for private life, there are compelling reasons for specifically recognising this proposed new right. There is precedent for human rights which were once subsumed within broader rights or freedoms becoming specifically identified and explicitly protected as thinking or technology evolves. The right to the protection of personal data, ${ }^{26}$ carved out of the right to respect for private life, is a good example of human rights evolving in step with advances in technology, not inhibiting such advances. Similarly, the proposed right to be free to look up and not feel threatened would be a timely response to the invasion and erosion of personal autonomy to which people today are consciously or unconsciously exposed as a result of technological developments. This was emphasised at the London hearing, where Andrew Hoskins ${ }^{27}$ observed how 'our daily interactions on and with digital devices and networks have produced an excess of data which can be exploited for the purposes of surveillance, policing

\footnotetext{
${ }^{23}$ Department of Law, Bournemouth University.

${ }^{24}$ The Guardian, 11 August 1995: https://www.theguardian.com/world/1995/aug/11/warcrimes.marktran.

25 Professor of Contemporary Slavery, University of Nottingham: a leading authority on the relationship between slavery, globalisation and environmental destruction.

${ }^{26}$ Art 8(1) of the Charter of Fundamental Rights of the European Union, [2010] OJ C 83/389.

${ }^{27}$ Media Sociologist and Interdisciplinary Research Professor of Global Security, University of Glasgow.
} 
and warfare' and William Merrin ${ }^{28}$ warned that we are facing 'data totalitarianism'.

More fundamentally still, there is something very special about having the freedom to look up at the sky without feeling threatened. Relationships with the sky run deep across cultures, spaces and time. The sky can teach us about the cosmos and how the universe functions. ${ }^{29}$ It teaches us perspective. The quotation attributed to Leonardo da Vinci, 'once you have tasted the taste of sky, you will forever look up', ${ }^{30}$ may have been intended to express his fascination with flight but it also captures something vital and life-enhancing about our relationship with the sky. That relationship is all too easily and permanently scarred, however. Addressing the International Court of Justice (ICJ) in March 2016, the Marshall Islands' Co-Agent Tony deBrum recalled how, as a boy, he had seen children playing in the radioactive dust that fell from the sky after a US thermonuclear bomb test there in $1954:^{31}$

'within five hours of the explosion, it began to rain radioactive fallout on Rongelap. Within hours the atoll was covered with a fine, white, powdered-like substance. No one knew it was radioactive fallout. The children thought it was snow...'32

In terms of its framing, the proposed right arguably strikes an appropriate balance between generality and specificity. As Conor Gearty explained at the London hearing, it is important to get that balance right:

'the more specific you get, the more [a right] resembles legislation. The more it resembles legislation, the more it's specific to the moment. The beauty of the language of human rights is that it's at a sufficient level of generality to be able to move with the times. It creates a momentum for control, which can then be built on... So we can create a momentum for change without necessarily, in singular acts, achieving change. And

\footnotetext{
${ }^{28}$ Senior Lecturer in Media Studies in the Department of Political and Cultural Studies at Swansea University.

${ }^{29}$ Kirsten Banks, 'Aboriginal astronomy can teach us about the link between the sky and the land', The Guardian, 21 May 2018: https://www.theguardian.com/commentisfree/2018/may/21/aboriginal-astronomycan-teach-us-about-the-link-between-sky-and-land.

30 'Leonardo on Painting: An Anthology of Writings by Leonardo da Vinci with a Selection of Documents Relating to his Career', ed Martin Kemp (Yale University Press, 2001).

${ }^{31} 67$ nuclear weapons were detonated in the Marshall Islands between 1946 and 1958 while the Islands were administered by the US under UN trusteeship.

32 Marshall Islands v Pakistan, 8 March 2016, opening statement by Tony deBrum, para 2: https://www.icjcij.org/files/case-related/159/159-20160308-ORA-01-00-BI.pdf.
} 
human rights has that capacity, as long as it stays general. The more general we can get, the more we can capture concerns in a fresh way and the more likely it is to be successful.'

A specific right to protect the freedom to live without physical or psychological threat from above would still be general enough to be able to move with the times and capture concerns in a fresh way. Furthermore, if the freedom to look up and not feel threatened were recognised in International Human Rights Law (IHRL), this would enhance protection under International Humanitarian Law $(\mathrm{IHL})$ and could help to make the latter more effective. ${ }^{33}$ It is important to emphasise that in proposing this new human right we are not advocating a pacifist position or denying the right to use armed force in accordance with the UN Charter. ${ }^{34}$

How would the proposed human right strengthen International Humanitarian Law?

One consequence of recognising the proposed human right would be that in armed conflict more weight would have to be given to psychological harm caused by aerial or airborne threats. This is because of 'systemic integration', a principle of interpretation enshrined in Article 31(3)(c) of the Vienna Convention on the Law of Treaties 1969. ${ }^{35}$ As Vito Todeschini explains, 'International bodies have constantly employed this principle to connect IHL and human rights law rules. $^{36}$

The ICJ has recognised that the protection offered by IHRL and that offered by IHL may co-exist in situations of armed conflict. In its judgment in Armed Activities on the Territory of the Congo, ${ }^{37}$ with reference to its advisory opinion

\footnotetext{
${ }^{33} \mathrm{IHL}$ is 'a set of rules that seek to limit the effects of armed conflict [and which] protects people who are not or are no longer participating in hostilities and restricts the means and methods of warfare.' See International Committee of the Red Cross, 'War \& Law': https://www.icrc.org/en/war-and-law.

${ }^{34}$ With the authority of the UN Security Council or in exercise of the inherent right of self-defence.

${ }^{35}$ Art 31(3)(c) provides that when interpreting a treaty, [t]here shall be taken into account [...] any relevant rules of international law applicable in the relations between the parties'.

${ }^{36}$ Vito Todeschini, 'The Relationship between International Humanitarian Law and Human Rights Law in the African Commission's General Comment on the Right to Life', EJIL: Talk!, June 7 2016:

https://www.ejiltalk.org/the-relationship-between-international-humanitarian-law-and-human-rights-law-inthe-african-commissions-general-comment-on-the-right-to-life/

${ }^{37}$ Democratic Republic of the Congo (DRC) v Uganda, ICJ Reports 2005, p 168.
} 
on The Legal Consequences of the Construction of a Wall in the Occupied Palestinian Territory, ${ }^{38}$ the Court observed:

'the protection offered by human rights conventions does not cease in case of armed conflict, save through the effect of provisions for derogation of the kind to be found in Article 4 of the International Covenant on Civil and Political Rights. As regards the relationship between international humanitarian law and human rights law, there are thus three possible situations: some rights may be exclusively matters of international humanitarian law; others may be exclusively matters of human rights law; yet others may be matters of both these branches of international law' ${ }^{39}$

In the light of ICJ case law, the European Court of Human Rights has noted that 'even in situations of international armed conflict, the safeguards under the [European] Convention continue to apply, albeit interpreted against the background of the provisions of international humanitarian law'. ${ }^{40}$ Since the principle of systemic integration requires rules of IHRL to be interpreted with reference to rules of $\mathrm{IHL}$, the converse must also be true: $\mathrm{IHL}$ rules should be interpreted in the light of IHRL.

For an example of how, through systemic integration, the proposed human right could strengthen protection under IHL, let us take Article 51(2) of Protocol I of 1977 Additional to the Geneva Conventions of 1949 and relating to the Protection of Victims of International Armed Conflicts ('Additional Protocol I'). ${ }^{41}$ This prohibits

'Acts or threats of violence the primary purpose of which is to spread terror among the civilian population'. ${ }^{42}$

As the International Criminal Tribunal for the Former Yugoslavia recognised,

'The object and purpose of Article 51(2) of Additional Protocol I is to confirm both the customary rule that civilians must enjoy general

\footnotetext{
38 ICJ Reports 2004, p 136, at p 178, para 106.

${ }^{39}$ Democratic Republic of the Congo (DRC) v Uganda, above, para 216.

${ }^{40}$ Application No 29750/09, Hassan v United Kingdom, Grand Chamber, 16 September 2014, para 104.

${ }^{41}$ UNTS, vol 1125, 1-17512. Additional Protocol I entered into force on 7 December 1978.

42 There is an identical prohibition in Article 13(2) of Additional Protocol II relating to the Protection of Victims of Non-International Armed Conflicts. IHL thus 'prohibits acts of terror in both international and noninternational armed conflict, irrespective of whether they are committed by State or non-State parties'. See Pfanner, T., 'Scope of Application, Perpetrators of Terror, and International Humanitarian Law', in: FernándezSánchez (Ed.), International Legal Dimensions of Terrorism (Martinus Nijhoff, 2009), p 289.
} 
protection against the danger arising from hostilities and the customary prohibition against attacking civilians. The prohibition of acts or threats of violence [stems] from the unconditional obligation not to target civilians for any reason, even military necessity. ${ }^{43}$

However, the drafting history of Article 51(2) shows that the prohibition of acts or threats of violence which have the primary object of spreading terror applies only to

'intentional conduct specifically directed toward the spreading of terror and excludes terror which was not intended by a belligerent and terror that is merely an incidental effect of acts of warfare which have another primary object and are in all other respects lawful. ${ }^{.44}$

The proposed new human right would help to close that gap by providing legal protection against unintended or incidental terror which for civilians on the ground is surely just as damaging as intended terror. The rules of IHL designed to protect civilians, including the rule of proportionality prohibiting attacks expected to cause excessive incidental injury to civilians (i.e. incidental injury that would be excessive compared to the anticipated military advantage), ${ }^{45}$ would have to be interpreted with reference to the right to live without physical or psychological threat from above.

A recent Chatham House research paper ${ }^{46}$ concluded that while there is no reason in principle to exclude mental harm from that proportionality assessment, the majority of State practice examined by the paper's author did not take mental harm into account. ${ }^{47}$ It was unclear whether that was 'because states do not consider that they are legally obliged to do so, or because of the practical challenges... of identifying and quantifying the mental harm expected from a particular attack' ${ }^{48}$ Regarding the latter, the paper noted that 'Civilians are frequently exposed to hostilities for prolonged periods, making it difficult to determine whether a particular attack is likely to cause mental harm ${ }^{\prime 49}$ and that

\footnotetext{
${ }^{43}$ Prosecutor v Stanislav Galić, ITCY Appeals Chamber, IT-98-29-A, 30 November 2006, para 103: http://www.icty.org/x/cases/galic/acjug/en/gal-acjud061130.pdf.

$44 \mathrm{Ibid}$, citing the Official Records of the Diplomatic Conference on the Reaffirmation and Development of International Humanitarian Law Applicable in Armed Conflicts, Geneva (1974-1977) Vol XV, p 274.

${ }^{45}$ See Art 51(5)(b) of Additional Protocol 1 and Art 8(2)(b)(iv) of the Rome Statute of the International Criminal Court.

${ }^{46}$ Emanuela-Chiara Gillard, 'Proportionality in the Conduct of Hostilities: The Incidental Harm Side of the Assessment', Chatham House, The Royal Institute of International Affairs, December 2018.

47 Ibid, para 115.

48 Ibid.

49 Ibid, para 112.
} 
'the occurrence of mental harm is more subjective than that of physical harm [which] makes it more difficult to foresee', the effects on mental health of exposure to an attack being 'likely to vary significantly, both among individuals and also depending on the context of where an attack occurs'. ${ }^{50}$

The need to think more about 'harm over time' was emphasised by Professor Andrew Byrnes, ${ }^{51}$ Counsel to the Airspace Tribunal in Sydney, after we had heard what it was like to live under the constant threat of aerial bombardment during the Iran-Iraq war and how psychological trauma experienced then continues today because of the ongoing threat of war. By removing any doubt that mental harm must be taken into account as part of the proportionality assessment required by $\mathrm{IHL}$, recognition of the proposed human right could well lead to better understanding of the mental health effects of attacks and incentivise belligerents to develop more appropriate 'collateral-damage estimation methodologies'. ${ }^{52}$

\section{How should the proposed new human right be created?}

The right could be recognised by the courts through a dynamic extension of existing rights (e.g. life, liberty and security, privacy). However, in the interests of certainty and legitimacy it would be better to create a specific right through the normal international and domestic political processes. In the third of his 2019 Reith Lectures, former UK Supreme Court Justice Jonathan Sumption criticised the 'mission creep' brought about by what he described as the European Court of Human Rights' tendency to develop the European Convention on Human Rights 'by a process of extrapolation or analogy so as to reflect its own view of what additional rights a modern democracy ought to have'. ${ }^{53}$ He continued:

'Many people will feel that some, at least, of the additional rights invented by the Strasbourg Court ought to exist. I think so myself. But the real question is whether the decision to create them ought to be made by

\footnotetext{
$50 \mathrm{Ibid}$, para 113. The paper's author is less accepting of concerns about the difficulties of quantifying mental harm, i.e. assigning a weight to its occurrence, ibid, para 114.

${ }^{51}$ Professor of International law, University of New South Wales; former Chair of the Australian Human Rights Centre and rapporteur of the International Law Association's Committee on International Human Rights Law.

52 Gillard, above, para 116.

${ }^{53}$ From The Reith Lectures 2019: 'Law and the Decline of Politics', Jonathan Sumption, Lecture 3: 'Human Rights and Wrongs', 4 June 2019:

http://downloads.bbc.co.uk/radio4/reith2019/Reith 2019 Sumption lecture 3.pdf.
} 
judges. Judges exist to apply the law. It is the business of citizens and their representatives to decide what the law ought to be... In a democracy, the appropriate way of resolving such disagreements is through the political process. $^{.54}$

Without necessarily agreeing with Lord Sumption's criticism of the European Court's 'living instrument' approach to the interpretation of the Convention, ${ }^{55}$ there is something to be said for the proposed new right being created through the political process with the active involvement of citizens around the world rather than by international, regional or even domestic courts.

\section{Conclusion}

In her closing speech at the London hearing of the Airspace Tribunal, Kirsty Brimelow QC emphasised that in the end 'we come back to a real fundamental - the dignity of people, the universality of human rights, and how we are communicating those things'. Noting that in other jurisdictions beyond the UK (though ominously increasingly here too) there is a tendency to see international human rights as foreign law, she concluded:

'This is why it is important to use $\operatorname{art}^{56}$ and other ways of making that connection between rights, dignity and universality against a common threat... There is a keenness and enthusiasm from activists and NGOs to have more rights, and that starts a conversation and begins the analysis. But what is the point if the rights are reached for when people are in moments of distress and crisis? The conversation should be happening earlier, particularly when - because of technology - we are in very grave and serious times where the potential destruction of the planet is now on the list of concerns because of what is above our heads.'

The aim of these Airspace Tribunal hearings is to facilitate, continue and develop this vital conversation.

\footnotetext{
54 Ibid.

${ }^{55}$ For a critique, see Patrick O'Connor QC (Doughty Street Chambers), '“Judicial overreach': a response to Sumption', Counsel (August 2019): https://www.counselmagazine.co.uk/articles/judicial-overreach-aresponse-to-sumption.

${ }^{56}$ The Airspace Tribunal is also contributing to the development of Topologies of Air by Shona Illingworth, an installation examining the impact of accelerating geopolitical, technological and environmental change on the composition, nature and use of airspace. Topologies of Air is commissioned by The Wapping Project.
} 